\title{
Studies on the requirement of the young chick for vitamin $\mathbf{E}$
}

\author{
2.* The effects of different sources and levels of dietary lipids on \\ live-weight gain and body vitamin $E$ storage
}

By T. W. GRIFFITHS
Spillers Limited, Animal Nutrition Research Laboratory, Middle Aston House, Steeple Aston, Oxford

(Received 23 September 1960-Revised 30 January $196 \mathrm{r}$ )

There is considerable experimental evidence to show that the addition of unsaturated fats to purified diets low in vitamin $\mathrm{E}$ gives rise to signs of vitamin $\mathrm{E}$ deficiency in young chicks. Zacharias, Goldhaber \& Kinsey (1950) produced encephalomalacia by adding $5 \%$ cod-liver oil to a basal diet similar to Dam's (1944a) diet 182 . Singsen, Bunnell, Matterson, Kozeff \& Jungherr (1955) encountered a high rate of mortality on adding as little as $2 \%$ of a good-quality feeding oil to a basal diet low in vitamin $\mathrm{E}$. They also found a depression in both rate of weight gain and serum tocopherol level in the surviving chicks, the magnitude of the effect increasing with the oil content of the diet.

Scott, Notzold \& Modler (1957) formulated a diet that when supplemented with $3 \%$ unsaturated fat, did not give rise to encephalomalacia or exudative diathesis. Previous experimental work in our laboratory (Griffiths, 1960 ) has failed to establish a dietary requirement for vitamin $\mathrm{E}$ in young chicks fed on a variety of purified diets all containing $3 \%$ arachis oil. Such diets, however, contained selenium, which has been shown to be as effective as $\alpha$-tocopherol in preventing signs of vitamin $E$ deficiency (Stokstad, Patterson \& Milstrey, 1957; Reid, Rahman, Creech \& Couch, 1958; Nesheim \& Scott, r958).

Animal fat is frequently added to the diets of broiler chicks to increase the energy intake, and commercial feeds may contain up to 8 or $9 \%$ total lipids. The object of the experiments reported below was to investigate the effects on the vitamin $\mathrm{E}$ requirement of broiler chicks of the addition to their diet of up to $10 \%$ of vegetable or animal fat. The purified diet was low in vitamin $\mathrm{E}$ but contained 0.8 p.p.m. selenium added as $\mathrm{SeO}_{2}$. The criteria of sufficiency adopted were live-weight gain, food-conversion efficiency and tocopherol level in blood and liver. Some measurements of creatine content of muscle were also made, and histological examination of brain tissues was carried out on birds from some of the treatments.

* Paper no. I : Brit. F. Nutr. (1960), 14, 269. 


\section{EXPERIMEN'TAL}

Treatment of the chicks. The chicks used were males of a commercial broiler strain (New Hampshire-Light Sussex $\times$ White Rock), and were obtained day-old from a hatchery. Management and collection of records were as previously described (Griffiths, 1960).

Design of experiments. Two experiments were done, each consisting of a similar $3 \times 2$ factorial arrangement of treatments. The treatments were: three levels of added fat, $5,7.5$ and $\mathrm{ro} \%$, and either no vitamin $\mathrm{E}$, or $2.72 \mathrm{mg}$ DL- $\alpha$-tocopheryl acetate/ roo $\mathrm{g}$ diet. In the first experiment the source of fat was refined deodorized arachis oil (British Oil and Cake Mills Limited, Erith) and in the second experiment stabilized bone tallow (Sheppy Glue and Chemical Works Ltd, Horley, Surrey). Groups of fifteen birds were caged and fed in units corresponding to treatments. Vitamin $\mathrm{E}$ was added as synthetic DL- $\alpha$-tocopheryl acetate 10 \% premix (Roche Products Ltd, Welwyn Garden City, Herts), and the level of $2 \cdot 72 \mathrm{mg} / 100 \mathrm{~g}$ diet was chosen because it had given the most satisfactory results in previous experiments; it corresponded roughly to the requirement of the chick for vitamin $\mathrm{E}$ as established by Singsen et al. (1955) and Scott, Norris, Heuser \& Nelson (1955).

\section{Table I. Percentage composition of the basal diets}

\begin{tabular}{|c|c|c|c|c|c|c|}
\hline \multirow{2}{*}{$\begin{array}{c}\text { Ingredient } \\
\text { Casein (fat and vitamin free)* }\end{array}$} & \multicolumn{3}{|c|}{ Expt no. I } & \multicolumn{3}{|c|}{ Expt no. 2} \\
\hline & 15.0 & $16 \cdot 0$ & $17 \cdot 0$ & $15 \cdot 0$ & $16 \cdot 0$ & $17 \cdot 0$ \\
\hline Albumin (blood) & $10 \cdot 0$ & $10 \cdot 0$ & $10 \cdot 0$ & 1000 & 10.0 & $10 \cdot 0$ \\
\hline Maize starch & 一 & - & - & $52 \cdot 0$ & $48 \cdot 5$ & $45^{\circ} \mathrm{O}$ \\
\hline Wheat starch & $62 \cdot 0$ & $58 \cdot 5$ & $55^{\circ} \circ$ & - & - & - \\
\hline Sucrose & - & - & - & $10 \cdot 0$ & $10 \cdot 0$ & $10 \cdot 0$ \\
\hline $\begin{array}{l}\text { Arachis oil (containing } 0.01 \% \\
\text { hydroquinone) } \dagger\end{array}$ & $5 \cdot 0$ & $7 \cdot 5$ & $10 \cdot 0$ & - & - & - \\
\hline $\begin{array}{l}\text { Stabilized bone tallow (containing } \\
0.02 \% \text { butylated hydroxytoluene) }\end{array}$ & - & - & - & $5 \cdot 0$ & $7 \cdot 5$ & $10 \%$ \\
\hline Filter-paper (ground) & $2 \cdot 0$ & $2 \cdot 0$ & $2 \cdot 0$ & $2 \cdot 0$ & $2 \cdot 0$ & 2.0 \\
\hline Mineral mixture§ & $6 \cdot 0$ & $6 \cdot 0$ & 6.0 & $6 \cdot 0$ & $6 \cdot 0$ & $6 \cdot 0$ \\
\hline
\end{tabular}

To I $\mathrm{kg}$ of basal diet were added I $0000 \mathrm{i} . \mathrm{u}$. vitamin $\mathrm{A}$, 1000 i.u. cholecalciferol, $2 \cdot 0 \mathrm{mg}$ menaphthone, $4^{\circ} \circ \mathrm{mg}$ thiamine hydrochloride, $10.0 \mathrm{mg}$ riboflavin, $50.0 \mathrm{mg}$ nicotinic acid, $8.0 \mathrm{mg}$ pyridoxine, $30.0 \mathrm{mg}$ calcium-D-pantothenate, $0.5 \mathrm{mg}$ biotin, $1.5 \mathrm{mg}$ folic acid, $1 \mathrm{~g}$ inositol, $50 \mathrm{mg} p$-aminobenzoic acid, $0.04 \mathrm{mg}$ cyanocobalamin, $2 \mathrm{~g}$ choline chloride, $0.5 \mathrm{~g}$ ascorbic acid, $0.125 \mathrm{~g}$ Nicarbazin $\left(4,4^{\prime}\right.$-dinitrocarbanilide and 2-hydroxy-4,6-dimethylpyrimidine complex, May \& Baker Ltd, Dagenham), $0.02 \mathrm{~g}$ chlortetracycline hydrochloride, $5 \cdot 2 \mathrm{~g}$ glycine, $0.9 \mathrm{~g}$ arginine hydrochloride.

* British Drug Houses Ltd, Poole, Dorset.

$\dagger$ British Oil and Cake Mills Limited, Erith.

I Sheppy Glue and Chemical Works Ltd, Horley, Surrey.

$\S$ Percentage composition: $\mathrm{K}_{2} \mathrm{HPO}_{4}, 25 \cdot 0 ; \mathrm{CaCO}_{3}, 23.5 ; \mathrm{NaCl}$, I0.0; $\mathrm{MgSO}_{4} \cdot 7 \mathrm{H}_{2} \mathrm{O}, 8 \cdot 5$; $\mathrm{CaHPO}_{4} \cdot 2 \mathrm{H}_{2} \mathrm{O}, 30 \cdot 0 ; \mathrm{FeC}_{6} \mathrm{H}_{3} \mathrm{O}_{7} \cdot 5 \mathrm{H}_{2} \mathrm{O}, 2 \cdot 3 ; \mathrm{MnSO}_{4} \cdot 4 \mathrm{H}_{2} \mathrm{O}, 0.54 ; \mathrm{KIO}_{3}, 0.10 ; \mathrm{CuSO}_{4} \cdot 5 \mathrm{H}_{2} \mathrm{O}$, $0.03 ; \mathrm{ZnCl}_{2}, 0.025 ; \mathrm{CoCl}_{2}, 0.003 ; \mathrm{SeO}_{2}, 0.002$.

Diets. The basal diets were developed from those used in earlier experiments (Griffiths, 1960) and contained a modified mineral mixture. Details of composition are given in Table $\mathbf{I}$. In the second experiment maize starch was used merely because it was more readily available than wheat starch; sucrose was also introduced in an attempt to improve palatability. More casein was included in the diets higher in fat to 
maintain a constant ratio of energy to protein. Both the arachis oil and the bone tallow contained added anti-oxidants (see Table I) to ensure their stability in the diet.

Collection of material. All birds were killed at 6 weeks of age. Livers were removed, and samples of blood and leg muscle were taken for chemical analysis. Material not immediately required was stored at $-20^{\circ}$.

Histological and biochemical methods. Histological examination of brain specimens and chemical determination of tocopherols in blood serum and liver were carried out as previously described (Griffiths, I960). Creatine in fresh muscle was determined by the method of Rose, Helmer \& Chanutin (1927). The individual fatty acids in both arachis oil and bone tallow were separated and estimated by means of gas-liquid chromatography (N. W. R. Daniels, private communication).

\section{RESULTS}

Rate of live-weight gain and food-conversion efficiency. In general the chicks grew satisfactorily during the experimental period. No encephalomalacia was seen. Exudative diathesis was found in four chicks, all on the diets containing arachis oil. However, it was unrelated to the level of vitamin $\mathrm{E}$ in the diet and occurred during the 2nd week of life. Overall mortality was $3.9 \%$.

Particulars of live-weight gain and food-conversion efficiency are given in Table 2. Analysis of variance was carried out on the treatment means in both experiments. Addition of $\alpha$-tocopherol to the diets of the chicks resulted in a significant overall increase in weight gain to 6 weeks of age. This effect was apparent at all levels of added fat but was significant only at the 7.5 and $10 \%$ fat levels. Birds on the bonetallow diets showed significantly better live-weight gains than those on the arachis-oil diets. This effect was apparent at all levels of added fat.

Food-conversion efficiency was not affected by supplementing the diets with $\alpha$-tocopherol; it was, however, significantly improved by increasing the level of fat in the diets from 5 to $10 \%$.

Post-mortem and histological findings. All birds appeared normal on post-mortem examination, except that a few had enlarged proventriculi. This abnormality has recently been shown to occur on diets with a texture similar to that of the diets used in these experiments (O'Dell, Newberne \& Savage, 1959).

Histological examination of brain specimens from all birds on the diets containing I0\% arachis oil showed no macroscopic or microscopic lesions that could be attributed to vitamin $\mathrm{E}$ deficiency.

Dietary constituents. The results of chemical assay for vitamin E content, degree of unsaturation and individual fatty-acid make-up of both arachis oil and bone tallow are given in Table 3.

Serum tocopherols. Summarized results for serum tocopherol values for all birds in both experiments are given in Table 4. No tocopherols could be detected in the serum of birds on the unsupplemented bone-tallow diets.

The treatment effects appeared to be multiplicative rather than additive, hence the responses were transformed into logarithms for the purposes of the analysis of variance. 
.

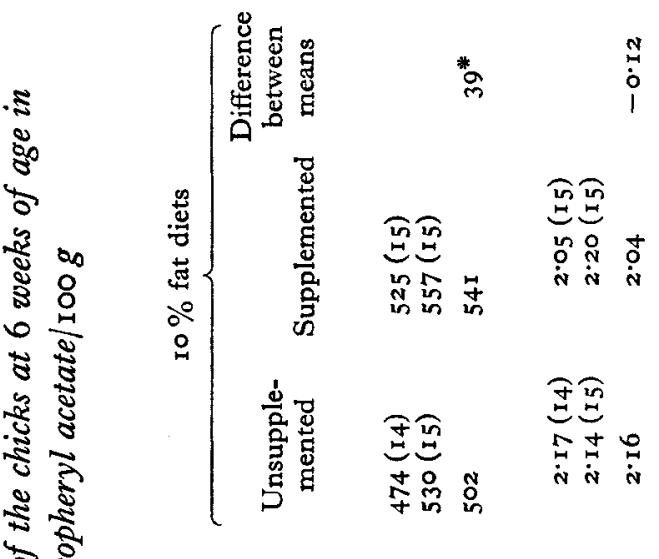

$\rightarrow \frac{8}{8}$

๑)

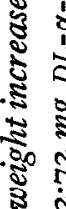

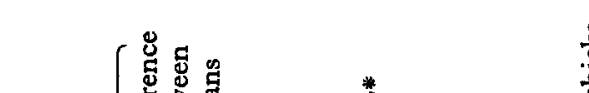

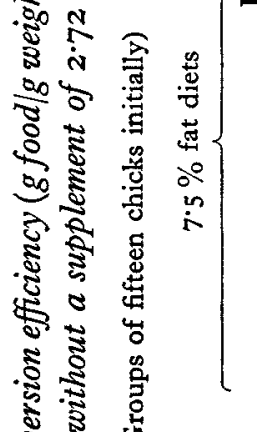

总

की

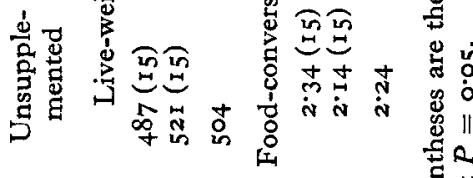

एक

造 $\frac{2}{2}$

จุำ

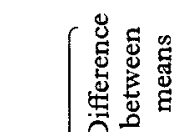

요

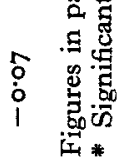

कo

总

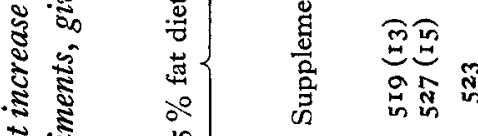

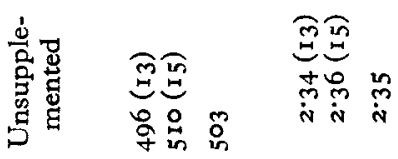

这

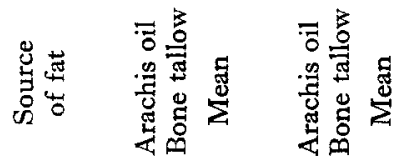


Undetectable amounts of tocopherol were taken as zero, and $\log (\mathrm{I}+$ concentration $\times 100)$ was analysed. For convenience the values in the tables are expressed in the usual arithmetic form.

Birds on the arachis-oil diets had significantly higher serum concentrations of tocopherol, owing no doubt to the fact that arachis oil contained measurable amounts of $\alpha$-tocopherol, whereas bone tallow did not (see Table 3 ).

Table 3. Comparison of the chemical compositions of the arachis oil and bone tallow used in the experiments

\begin{tabular}{|c|c|c|}
\hline Component & Bone tallow & Arachis oil \\
\hline$\alpha$-Tocopherol (mg/g) & None detected & O.II \\
\hline$\gamma$-Tocopherol (mg/g) & None detected & 0.15 \\
\hline \multicolumn{3}{|c|}{ Fatty acids as methyl esters $(\%)$} \\
\hline Myristic & $x \cdot 8$ & - \\
\hline $\mathrm{C}_{16}$ & 0.6 & - \\
\hline Palmitic & $18 \cdot 1$ & $8 \cdot 6$ \\
\hline Palmitoleic & 4.0 & - \\
\hline $\mathrm{C}_{17}$ & $2 \cdot 7$ & - \\
\hline Stearic & $15 \cdot 3$ & $4 \cdot 7$ \\
\hline Oleic & $35 \cdot 3$ & $52 \cdot 9$ \\
\hline Linoleic & 5.0 & 23.8 \\
\hline Linolenic & - & 0.9 \\
\hline Arachidic & - & $1 \cdot 4$ \\
\hline $\mathrm{C}_{20}$ (unsaturated) & - & $1 \cdot 4$ \\
\hline Arachidonic & - & $1 \cdot 6$ \\
\hline Behenic & - & 2.I \\
\hline Undetected & $17 \cdot 2$ & $2 \cdot 6$ \\
\hline Iodine value & 55 & 92 \\
\hline
\end{tabular}

Supplementation of the diets with $\alpha$-tocopherol gave at each level of added fat a significant increase in serum tocopherol concentration. There was a highly significant interaction between the addition of tocopherol to the diets and the source of fat used. It resulted from the much greater response to $\alpha$-tocopherol found on the bone-tallow diets compared with the arachis-oil diets.

Tocopherols in liver. Summarized values for liver tocopherol are also presented in Table 4. For statistical analysis they were treated as for serum tocopherols, and the results are broadly similar.

Again, supplementing the diets with $\alpha$-tocopherol gave a highly significant increase in tocopherol storage in the liver. The effect was consistent at all levels of added fat but suggested a different trend for the two sources of fat, a much higher response by $\alpha$-tocopherol storage in the liver being obtained on the bone-tallow diets than on the arachis-oil diets.

Muscle creatine. Muscular degeneration due to vitamin E deficiency is accompanied by reduced concentrations of muscle creatine in several species (Blaxter \& McGill, 1955). The mean values with their standard errors for creatine in seven samples of leg muscle taken immediately after death from birds on diets containing $10 \%$ stabilized bone tallow were: without tocopherol $3.15 \pm 0.07$ and with tocopherol $3.25 \pm 0.05 \mathrm{mg} / \mathrm{g}$ fresh tissue. The standard errors are not strictly appropriate for testing the treatment difference since the birds were fed as groups. 


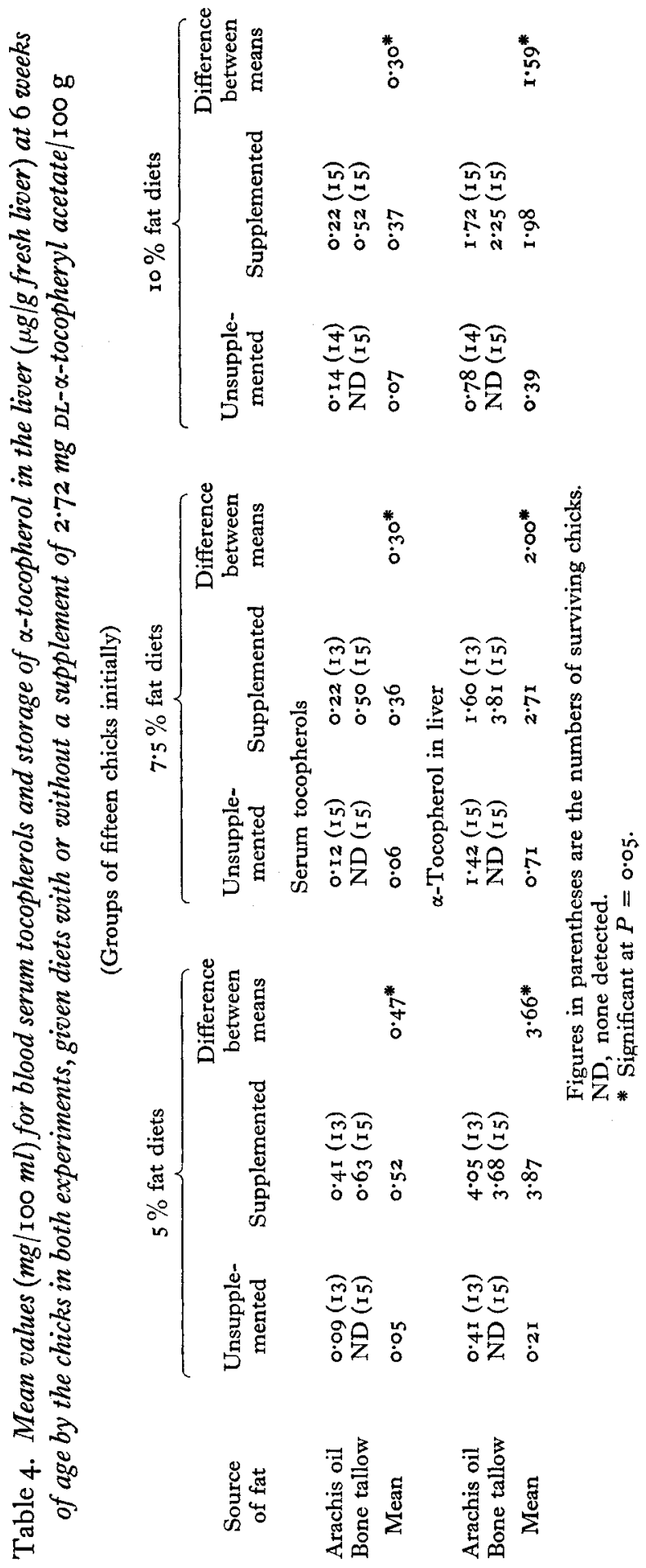




\section{DISCUSSION}

The basal diets used in these experiments proved to be more satisfactory than those used previously (Griffiths, I960). Mortality was reduced from about 16 to under $4 \%$. Again no encephalomalacia occurred, and although exudative diathesis was found its appearance was not related to the level of $\alpha$-tocopherol in the diet.

The results clearly confirm the findings of Singsen et al. (1955) that addition of oil to a purified diet low in vitamin $\mathrm{E}$ can depress rate of weight gain and serum tocopherol concentration in young chicks. However, growth depression in the absence of additional tocopherol did not become significant until $7.5 \%$ of oil was included. The extent of the growth depression and also the response in blood and liver tocopherol values to additional $\alpha$-tocopherol appeared to bear some relation to the degree of unsaturation of the oils used, since the iodine value of the fish oil used by Singsen $e t$ al. was about $\mathrm{1} 3 \mathrm{O}$, compared with 92 for arachis oil and 55 for the stabilized tallow used by me. Bieri, Briggs, Pollard \& Fox (1960) found vitamin E not to be essential for normal growth and development in the chick, even when the diet contained $10 \%$ lard.

Again, compared with values found in previous experiments with basal diets similar but containing only $3 \%$ arachis oil (Griffiths, 1960 ), the responses in serum tocopherol concentrations to a supplement of $2 \cdot 72 \mathrm{mg}$ DL- $\alpha$-tocopheryl acetate/100 g diet were markedly reduced when $5 \%$ arachis oil or more was included in the diet. However, tocopherol storage in the liver was not affected until $7.5 \%$ arachis oil or 10 $\%$ bone tallow was included.

The finding of Scott et al. (1957) that the content of muscle creatine was increased by the addition of $\alpha$-tocopherol to a purified diet very low in vitamin $E$ was not confirmed. However, the diets of Scott $e t$ al. contained no added selenium.

The presence of additional vitamin $\mathrm{E}$ would seem to be desirable for young chicks if the diet contains vegetable oil at a level of $5 \%$ or above, or animal tallow at about I0 $\%$. It is suggested that under these conditions certain constituents of the fat could reach critical concentrations and depress live-weight gain unless adequate $\alpha$-tocopherol is present. The lowered concentrations of tocopherol in serum and liver found with supplemented diets high in fat indicate that some tocopherol was destroyed or antagonized.

The correlation between the degree of unsaturation of the oil and the extent of depression in live-weight gain has been mentioned above and indicates that unsaturated fatty acids are involved (cf. Dam, 1944b). Linoleic acid has recently been shown by Machlin, Knickerbocker \& Gordon (1959) and Century \& Horwitt (1959) to be a primary factor in the production of encephalomalacia in the chick.

The arachis oil used in my experiments contained $23 \%$ linoleic acid but the stabilized tallow only $5 \%$. Thus the diets containing 7.5 and $10 \%$ arachis oil contained about $\mathrm{I} 8$ and $23 \mathrm{~g}$ linoleic acid/kg, respectively. Century \& Horwitt (1959) showed that diets containing at least $14 \mathrm{~g}$ linoleic acid/ $\mathrm{kg}$ were capable of inducing encephalomalacia in tocopherol-deficient chicks. The relevant chicks in this experiment were not considered to be severely deficient in tocopherols since measurable amounts 
were found in liver and in blood serum, but there would appear to have been insufficient to maintain maximum rate of gain in live weight.

Thus, although a dietary level of vitamin E equivalent to less than $0.3 \mathrm{mg}$ DL- $\alpha$-tocopherol was adequate for young chicks on a diet containing $3 \%$ arachis oil (Griffiths, 1960), $\mathrm{x} \cdot 0 \mathrm{mg} / \mathrm{r} 00 \mathrm{~g}$ was not sufficient when the diet contained $10 \%$ arachis oil. Similar results were found by Moore, Sharman \& Ward (1959) for rats given cod-liver oil.

Zacharias et al. (1950) have quoted $500 \mu \mathrm{g} / \mathrm{I} 00 \mathrm{ml}$ for total tocopherols in blood serum as the value below which signs of encephalomalacia could occur in chicks fed on certain diets. It would appear from the experiments recorded here that growth depression is likely in chicks fed on diets high in oil if serum tocopherols fall below $200 \mu \mathrm{g} / 100 \mathrm{ml}$. It would also seem likely that liver storage of over $2 \mu \mathrm{g} \alpha$-tocopherol $/ \mathrm{g}$ fresh liver is desirable for chicks fed on high-fat diets. These levels were in general maintained by a supplement of $2-3 \mathrm{mg}$ vitamin $\mathrm{E} / \mathrm{100} \mathrm{g}$ diet.

\section{SUMMARY}

I. Groups of fifteen day-old chicks were fed for 6 weeks on purified basal diets low in vitamin $\mathrm{E}$ but containing 0.8 p.p.m. added selenium, and the effects of $5,7.5$ and ro $\%$ of added fat with and without supplementary tocopherol were compared in a factorial arrangement. Arachis oil and stabilized bone tallow were used as sources of fat in two experiments. Weight gains and food consumptions were measured. Concentrations of tocopherol in serum and liver were determined at 6 weeks of age.

2. The birds made significantly better gains in weight when supplementary $\alpha$-tocopherol was included in the diet. Increasing the level of oil improved the foodconversion efficiency.

3. Supplementing the diets with $\alpha$-tocopherol resulted in highly significant increases in tocopherol concentrations in serum and liver. The responses were much higher in birds fed on the bone-tallow diets than in those fed on the arachis-oil diets, and there was a tendency for these responses to decline as the lipid content of the diet was increased.

4. The results are discussed in relation to the unsaturated fatty-acid, and particularly the linoleic-acid, content of the fats used.

5. It is concluded that the vitamin $E$ requirement of the chick cannot be fixed on an absolute scale, but varies over a wide range according to the criteria of deficiency adopted and the nature of the lipid fraction of the diet.

6. It is suggested that a level of about $3 \mathrm{mg}$ DL- $\alpha$-tocopheryl acetate/Ioo $\mathrm{g}$ diet is desirable for young chicks fed on diets including more than $5 \%$ of an added fat with an iodine value higher than 90 .

I am grateful to Dr N. W. R. Daniels for determining the individual fatty acids in the fats used and to Mr M. W. Barwick for the histological examination of brain specimens. 


\section{REFERENCES}

Bieri, J. G., Briggs, G. M., Pollard, C. J. \& Fox, M. R. S. (I960). F. Nutr. 70, 47.

Blaxter, K. L. \& McGill, R. F. (I955). Vet. Rev. Annot. r, 9 I.

Century, B. \& Horwitt, M. K. (1959). Proc. Soc. exp. Biol., N. Y., 102, 375.

Dam, H. (1944a). F. Nutr. 27, r93.

Dam, H. (1944b). $\mathscr{F}$. Nutr. 27, 297.

Griffiths, T. W. (1960). Brit. $\mathcal{F}$. Nutr. 14, 269.

Machlin, L. J., Knickerbocker, K. A. M. \& Gordon, R. S. (1959). Poult. Sci. 38, 1224.

Moore, T., Sharman, I. M. \& Ward, R. J. (1959). Brit. F. Nutr. r3, 100.

Nesheim, M. C. \& Scott, M. L. (1958). F. Nutr. 65, 601.

O'Dell, B. L., Newberne, P. M. \& Savage, J. E. (1959). Poult. Sci. 38, 296.

Reid, B. L., Rahman, M. M., Creech, B. G. \& Couch, J. R. (1958). Proc. Soc. exp. Biol., N. Y., $97,590$.

Rose, W. G., Helmer, O. M. \& Chanutin, W. (1927). F. biol. Chem. 75, 543.

Scott, H. M., Notzold, R. A. \& Modler, M. W. (1957). Poult. Sci. 36, 949.

Scott, M. L., Norris, L. C., Heuser, G. F. \& Nelson, T. S. (r955). Poult. Sci. 34, 1220.

Singsen, E. P., Bunnell, R. H., Matterson, L. D., Kozeff, A. \& Jungherr, E. L. (1955). Poult. Sci. 34, 262.

Stokstad, E. L. R., Patterson, E. L. \& Milstrey, R. (r957). Poult. Sci. 36, 1160.

Zacharias, L., Goldhaber, P. \& Kinsey, V. E. (1950). F. Nutr. 42, 359. 